\title{
Development of the cross sectional area of flexor tendons in the metacarpal region of 2-year-old horses of different breeds
}

\author{
Andreas Kösterl', Arno Lindner ${ }^{7}$ and Hartmut Gerhards² \\ Arbeitsgruppe Pferd, Jülich \\ 2 Ludwig-Maximilian-Universität München, Klinik für Pferde, München
}

Summary: This study examined the development of the CSA of the superficial and deep digital flexor tendon (SDFT and DDFT) and of the accessory ligament of the DDFT (AL-DDFT) in both forelimbs of six 2-year-old Thoroughbreds (TB), ten 2-year-old Standardbreds (SB), five 2-year-old Quarterhorses (QH) and ten 2-year-old German Warmblood Riding horses (WB) during one year with the hypothesis that it would be different among breeds. The initial CSA measurements were done in the yearling QH in November and thereafter in March, July and November of their 2-year-old season, and in the horses of all other breeds the measurements were in January, April, August and December of their 2-year-old year. The CSA was measured with ultrasound at four $\mathrm{cm}$ intervals, starting four $\mathrm{cm}$ distal from the distal border of the accessory carpal bone down to the metacarpophalangeal joint. The TB and SB were in race training, the WB were halter trained and the 2-year-old QH were schooled for western riding. For the SDFT, breed, CSA at specific distances distal to the distal border of the accessory carpal bone, $(p<0.001$ both) and the interaction of breed and the CSA at specific distances distal to the distal border of the accessory carpal bone were significant $(p<0.05)$, but there was no significant difference between forelimbs $(p>0.05)$. The overall CSA from all measurements points was smallest in QH, largest in TB and WB, with SB having a CSA measurement between the other breeds. The overall CSA of SDFT in TB did not change during the observation period. However, in QH and WB there were significant decreases in the CSA, and these decreases varied between the CSA measured at specific distances distal to the distal border of the accessory carpal bone. In addition, in SB there were significant increases in the overall CSA measurement of the SDFT, followed by a decrease from August to December with CSA returning to initial values ( $p<0.05$ at least for all). For the DDFT too, breed, CSA at specific distances distal to the distal border of the accessory carpal bone, as well as the interaction of breed and the CSA at specific measurement points were significant $(p<0.001$ all), but there was no significant difference between forelimbs $(p>0.05)$. The overall CSA from all specific distances distal to the distal border of the accessory carpal bone of DDFT was smaller in QH than in the horses of the other breeds studied $(p<0.01)$. There were no significant differences in the overall CSA among the TB, SB and WB. Few changes in the CSA of DDFT at the measurement points occurred during the observation period in QH and TB. In contrast, the SB CSA in both forelimbs decreased at $4 \mathrm{~cm}, 8 \mathrm{~cm}$ and $12 \mathrm{~cm}$ during the year of observation. However, CSA increased $20 \mathrm{~cm}$ and $24 \mathrm{~cm}$ distal to the distal border of the accessory carpal bone between January and August, returning to the initial levels thereafter ( $p<0.05$ at least for all). In WB, CSA of DDFT decreased continuously during the observation period at several measurement points in both forelimbs $(p<0.01$ at least). For the AL-DDFT, CSA measurements were taken at $4 \mathrm{~cm}$ and $8 \mathrm{~cm}$ distal of the distal border of the accessory carpal bone only. The size of AL-DDFT CSA differed among breeds and specific distances distal to the distal border of the accessory carpal bone $(p<0.001$ both). QH had the smallest overall CSA ( $<<0.01$ at least) while among the horses of the other breeds, the overall CSA did not differ ( $p>0.05$ among all). The QH also did not have any change in the CSA of AL-DDFT during the observation year at any specific distance distal to the distal border of the accessory carpal bone or between limbs ( $p>0.05)$. In comparison, SB CSA of AL-DDFT increased at the $8 \mathrm{~cm}$ measuring point in the left forelimb between January and August and then decreased below the initial value by December $(p<0.01)$. There were no changes of CSA of AL-DDFT in the left forelimb of TB, while in the right forelimb CSA increased continuously at $4 \mathrm{~cm}$ and $8 \mathrm{~cm}$ distal to the distal border of the accessory carpal bone between January and August and then returned to the levels measured in January $(p<0.05)$. In WB CSA of AL-DDFT decreased continuously during the year of observation at all measurement points in both forelimbs ( $p<0.01$ at least). In conclusion, the development of the CSA of flexor tendons in 2-year-old horses varied markedly among breeds and during the year of observation. It remains to be proven whether the changes are due to genetics only or the management and especially the physical training of the horses played a role.

Keywords: horse /age / body weight / growth / ultrasound / training

\section{Entwicklung der Querschnittsfläche der Beugesehnen am Metakarpus von 2-jährigen Pferden verschiedener Rassen}

Die Entwicklung der Querschnittsfläche (QuerF) der Beugesehnen am Metakarpus von 2-jährigen Pferden ist bisher in der Praxis nicht untersucht worden und die Mehrheit der Studien über die Wirkung von Training auf die QuerF der Beugesehnen sind an Englischen Vollblütern (VB) gemacht worden. In dieser Untersuchung wurde die Entwicklung der QuerF der oberflächlichen Beugesehne (OberB), der tiefen Beugesehne (TiefB) sowie des Unterstützungsbandes der tiefen Beugesehne (UTiefB) beider Vordergliedmaßen von 6 VB, 10 Trabern (TB), 5 Quarterhorses (QH) und 10 Deutschen Warmblütern (WB) während eines Jahres verfolgt. Die Hypothese war, dass die Entwicklung dieser Strukturen zwischen den Rassen unterschiedlich verlaufen würde. Die erste Messung fand bei den QH als Jährlinge im November statt. Weitere Messungen wurden im folgenden März, Juli und November gemacht. Die Messungen bei den 2jährigen Pferden der anderen Rassen wurden im Januar, April, August und Dezember eines Jahres durchgeführt. Die Messungen erfolgten mittels Ultraschall vom distalen Ende des Os calcaneus im Abstand von $4 \mathrm{~cm}$ bis zum Metakarpus. Zu den selben Zeitpunkten wurde auch das Körpergewicht (KGW) und die Widerristhöhe (WH) der Pferde gemessen. Die VB und TB wurden auf Rennen vorbereitet und starteten auch zum Teil, die WB erhielten nur eine Grundausbildung am Halfter und die QH erfuhren eine Grundausbildung zum Westernreitpferd. Rasse, Messhöhe (beide $p<0,001)$ und die Wechselwirkung zwischen Rasse und Messhöhe $(p<0,05)$ hatten einen Effekt auf die QuerF der OberB. Es gab keine Unterschiede zwischen den Vordergliedmaßen $(p>0,05)$. Die QuerF der OberB war am niedrigsten bei den QH und am größten bei VB und WB. Die QuerF der OberB änderte sich im Verlauf der Untersuchung bei den VB nicht, verringerte sich bei QH und WB und vergrößerte sich bei TB bis August, um sich danach wieder zu verringern (mindestens $p<0,05$ für alle). Rasse, Messhöhe und Wechselbeziehung zwischen Rasse und Messhöhe hatten Effekte auf die QuerF der TiefB (alle $p<0,001$ ). Es gab keinen Unterschied zwischen den Vordergliedmaßen der 
Pferde. Die QuerF der TiefB war niedriger bei den QH im Vergleich zu den Pferden aller anderen Rassen $(p<0,01)$ und unterschied sich nicht zwischen den anderen Rassen. Im Verlauf des Beobachtungszeitraums traten wenige Veränderungen der QuerF der TiefB bei QH und VB auf, während sie an beiden Vordergliedmaßen der TB in 4, 8 und $12 \mathrm{~cm}$ Höhe abnahm und in 20 und $24 \mathrm{~cm}$ Höhe zwischen Januar und August zunahm, um danach wieder auf die Ausgangswerte zurück zu fallen (mindestens $p<0.05$ für alle). Die QuerF der TiefB von den WB nahm an den meisten Messhöhen bei beiden Vordergliedmaßen während der Untersuchung ab (mindestens $p<0,01$ ). Die QuerF des UTiefB konnte bei keinem QH und TB sowie bei einem WB und zwei VB bis zu einer Höhe von $8 \mathrm{~cm}$ von der TiefB getrennt gemessen werden. Deshalb wurden nur die Messhöhen 4 und $8 \mathrm{~cm}$ ausgewertet. Die QuerF des UTiefB entwickelte sich unterschiedlich zwischen den Rassen (beide $p<0,001)$. QH hatten die kleinsten QuerF, während sie sich zwischen den Pferden der anderen Rassen nicht unterschied ( $p<0.001$ zwischen QH und andere Rassen). Im Verlauf des Beobachtungsjahres blieb die QuerF des UTiefB bei den QH gleich und nahm in $8 \mathrm{~cm}$ Messhöhe bei den TB zwischen Januar und August zu, um danach wiederunter den Wert von Dezember zurück zu gehen ( $p<0,01$ ). In der linken Vordergliedmaße der VB änderte sich die QuerF nicht, während sie in der rechten Vordergliedmaße in 4 und $8 \mathrm{~cm} H o ̈ h e ~ b i s$ August zunahm, um danach auf die Ausgangswerte zurückzugehen $(p<0,05)$. Bei den WB nahm die QuerF an beiden Höhen beider Vordergliedmaßen im Verlauf des Jahres ab (mindestens $p<0,01$ ). Die Bündelung der Daten aller Pferde, Messhöhen und -zeitpunkte zeigte, dass mit zunehmenden KGW und höherer WH die QuerF der OberB in beiden Vordergliedmaßen zunahm ( $<<0,01$ bis 0,001$)$ während es nur wenige Beziehungen zur QuerF der TiefB und gar keine zur QuerF des UTiefB gab. Die Ergebnisse dieser Arbeit zeigen, dass sich die QuerF der Beugesehnen im Verlauf eines Jahres bei 2-jährigen Pferden unterschiedlicher Rassen sehr verschieden entwickeln. Es bleibt zu untersuchen, ob diese Veränderungen nur rassebedingt sind oder auch mit der Haltung der Pferde, insbesondere deren Training, zusammenhängen.

Stichwörter: Pferd / Alter / Körpergewicht / Training / Ultraschall / Wachstum / Orthopädie

Citation: Köster A., Lindner A., Gerhards H. (2014) Development of the cross sectional area of flexor tendons in the metacarpal region of 2-year-old horses of different breeds. Pferdeheilkunde 30, 54 1-550

Correspondence: Dr. Arno Lindner, Arbeitsgruppe Pferd, Heinrich-Roettgen-Str. 20, 52428 Juelich, Germany, E-mail: arnolindner@t-online.de

\section{Introduction}

The development of the cross sectional area (CSA) of flexor tendons in 2-year-old horses has not been followed in practice and there are few studies on the effect of physical training on the cross sectional area (CSA) of flexor tendons in horses, mainly in Thoroughbreds (TB; Gillis et al. 1993, Birch et al. 1999a, Kasashima et al. 2002, Perkins et al. 2004, Firth 2006, Moffat et al. 2008), one in Standardbreds (SB; Voswinkel 2009), and one in Dutch Warmblood Riding Horse foals (WB; Cherdchutham et al. 2001 a). The results of these studies do not allow for clear conclusions on the possible role of physical training on CSA due to the few types of exercise examined and one breed used mainly. Cherdchutham et al. (2001 a) observed that SDFT in Dutch WB foals with larger CSA ruptured at higher loads than that of Dutch WB with smaller CSA. This experimental finding is supported by Smith et al. (1994) observing in practice SDFT lesions in several TB horses having smaller CSA than horses without a lesion. Thus, increasing CSA of SDFT could reduce injury rate and therefore the threat on the sports career of horses.

Interventional physical training studies are very expensive in horses because of the time and effort involved. Therefore the examination of the development of the CSA of flexor tendons in horses of different breed could provide additional information at least on the magnitude of CSA changes. The measurement of CSA through ultrasound can be made readily and safely in practice without disrupting the management and training programs of horses (Birch et al. 1999 b). Thus, in this study the development of the CSA of the flexor tendons in 2year-old Quarterhorses (QH), SB, TB and German Warmblood Riding horses (WB) during one year was examined with the hypothesis that the CSA would develop differently among breeds. Overall the work should contribute information on the development of the CSA of the flexor tendons in young horses and eventually provide for new hypotheses on the possible effect of physical training.

\section{Material and Methods}

Horses

The study was done with horses that were under continuous commercial veterinary surveillance to monitor performance. The data of 10 SB (7 colts, 3 fillies), 10 WB (all colts), 6 TB (3 colts and 3 fillies) and $5 \mathrm{QH}$ (3 colts and 2 fillies) could be used for the evaluation. The CSA of SDFT, DDFT and ALDDFT of all horses was measured four times during 12 months. The first measurement of CSA in QH took place in November of their yearling age and thereafter in March, July and November of their 2-year-old season. All other horses were measured in January, April, August and December of their 2-year-old season. All horses of a breed were stabled in the same premise. The SB and TB were in training for racing (training described in Lindner et al. $1992 \mathrm{a}$ and b, Wegener et al. 2012), the QH were halter broken as yearlings and were further schooled for reining during their 2-year-old season while the WB were accustomed to saddle and bridle, gently ridden for few weeks and kept on pasture during the remainder of the year.

\section{Experimental procedure}

Horses were placed for all measurements in a quiet area of the respective barns on firm ground. Care was taken that the horses did not move significantly by placing an experienced horse handler holding the head. To determine the withers height $(\mathrm{WH})$, each horse was squared up and stood still while a commercially available measuring stick (no specific brand - rigid pole with a cross bar that could be raised or lowered to rest on the horse s withers) was used to determine in $\mathrm{cm}$ the withers height. The horizontal position of the cross bar was verified with a spirit level. The head of the horses was held in a comfortable position for the person holding the reins and the neck of the horses being somewhat higher proximal than distal to produce repeatable values (Lamas et al. 2007). 


\begin{tabular}{|c|c|c|c|c|c|}
\hline \multirow[b]{2}{*}{ Parameter } & \multirow[b]{2}{*}{ Month of measurement ${ }^{1}$} & \multicolumn{4}{|c|}{ Breed $(n)$} \\
\hline & & Quarterhorse (5) & Standardbred (10) & Thoroughbred (6) & $\begin{array}{c}\text { German Warmblood } \\
\text { Riding Horse (10) }\end{array}$ \\
\hline \multirow{4}{*}{$\begin{array}{c}\text { Body } \\
\text { weight } \\
(\mathrm{kg})\end{array}$} & November / January & $423 \pm 28$ & $423 \pm 22$ & $438 \pm 44$ & $513 \pm 26$ \\
\hline & March / April & $400 \pm 18$ & $429 \pm 26$ & $453 \pm 45$ & $505 \pm 35$ \\
\hline & July/August & $439 \pm 21$ & $458 \pm 27$ & $472 \pm 47$ & - \\
\hline & November/ December & $470 \pm 17$ & $461 \pm 41$ & $481 \pm 37$ & - \\
\hline \multirow{4}{*}{$\begin{array}{l}\text { Withers } \\
\text { height } \\
(\mathrm{cm})\end{array}$} & November / January & $141 \pm 4$ & $152 \pm 2$ & $157 \pm 2$ & $160 \pm 3$ \\
\hline & March / April & $144 \pm 3$ & $154 \pm 3$ & $158 \pm 4$ & $162 \pm 4$ \\
\hline & July/ August & $146 \pm 2$ & $156 \pm 3$ & $162 \pm 4$ & $164 \pm 3$ \\
\hline & November/ December & $147 \pm 3$ & $157 \pm 3$ & $164 \pm 2$ & - \\
\hline
\end{tabular}

${ }^{1}=1^{\text {st }}$ measurement of CSA in Quarterhorses took place in November of their yearling age and thereafter in March, July and November of their 2-year-old season. All other horses were measured in January, April, August and December of their 2-year-old season

Table 2 Relationship between cross sectional area of flexor tendons in 2-year-old horses of different breeds and their body weight (measurement points with a significant relationship only are shown). / Beziehung zwischen dem Querschnitt der Beugesehnen und dem Körpergewicht von 2iährigen Pferden unterschiedlicher Rassen (nur Messhöhen mit signifikanten Beziehungen sind aufgeführt)

\begin{tabular}{|c|c|c|c|c|c|}
\hline \multirow[t]{2}{*}{ Tendon } & \multirow[t]{2}{*}{ Limb } & \multirow{2}{*}{$\begin{array}{l}\text { Distance distal to the distal border } \\
\text { of the accessory carpal bone } \\
(\mathrm{cm})\end{array}$} & \multicolumn{3}{|c|}{$\begin{array}{c}\text { Breed }^{1} \\
\text { significance / }{ }^{2}\end{array}$} \\
\hline & & & Quarterhorse (5) & Standardbred (10) & Thoroughbred (6) \\
\hline \multirow{5}{*}{ SDFT } & Right & 8 & n.s. & $0.05 / .15$ & n.s. \\
\hline & Right & 12 & n.s. & $0.05 / .12$ & n.s. \\
\hline & Left & 16 & n.s. & $0.01 / .16$ & n.s. \\
\hline & Right & 16 & n.s. & $0.05 / .11$ & n.s. \\
\hline & Right & 20 & n.s. & $0.05 / .13$ & n.s. \\
\hline \multirow{3}{*}{ DDFT } & Left & 12 & n.s. & n.s. & $0.05 / .22$ \\
\hline & Right & 12 & n.s. & n.s. & $0.07 / .14$ \\
\hline & Left & 20 & n.s. & n.s. & $0.05 / .21$ \\
\hline \multirow{2}{*}{ AL-DDFT } & Right & 4 & $0.05 / .19$ & n.s. & n.s. \\
\hline & Left & 8 & $0.05 / .19$ & $0.05 / .12$ & n.s. \\
\hline
\end{tabular}

$\mathrm{I}^{\prime}=$ German Warmblood Riding Horses not analyzed due to missing data / n.s. $=p>0.05 /$ SDFT $=$ Superficial digital flexor tendon / DDFT = Deep digital flexor tendon / AL-DDFT = Accessory ligament of DDFT

Table 3 Relationship between cross sectional area of flexor tendons in 2-year-old horses of different breeds and their withers height (measurement points with a significant relationship only are shown). / Beziehung zwischen dem Querschnitt der Beugesehnen und der Widerristhöhe von 2jährigen Pferden unterschiedlicher Rassen (nur Messhöhen mit signifikanten Beziehungen sind aufgeführt.)

\begin{tabular}{|c|c|c|c|c|c|c|}
\hline \multirow{2}{*}{ Tendon } & \multirow{2}{*}{ Limb } & \multirow{2}{*}{$\begin{array}{l}\text { Distance distal to } \\
\text { the distal border of } \\
\text { the accessory } \\
\text { carpal bone } \\
(\mathrm{cm})\end{array}$} & \multicolumn{4}{|c|}{$\begin{array}{c}\text { Breed } \\
\text { significance } / r^{2} \\
\end{array}$} \\
\hline & & & $\begin{array}{c}\text { Quarterhorse } \\
\text { (5) }\end{array}$ & $\begin{array}{c}\text { Standardbred } \\
\text { (10) }\end{array}$ & $\begin{array}{c}\text { Thoroughbred } \\
\text { (6) }\end{array}$ & $\begin{array}{l}\text { German Warmblood } \\
\text { Riding Horse }(10)^{1}\end{array}$ \\
\hline \multirow{4}{*}{ SDFT } & Left & 16 & n.s. & $0.01 / .16$ & n.s. & n.s. \\
\hline & Right & 16 & n.s. & $0.05 / .11$ & n.s. & n.s. \\
\hline & Left & 20 & n.s. & $0.05 / .10$ & n.s. & n.s. \\
\hline & Right & 20 & n.s. & $0.05 / .10$ & n.s. & n.s. \\
\hline \multirow{2}{*}{ DDFT } & Left & 12 & n.s. & $0.001 / .24$ & $0.05 / .23$ & n.s. \\
\hline & Right & 12 & n.s. & $0.01 / .16$ & $0.05 / .20$ & n.s. \\
\hline \multirow{3}{*}{ AL-DDFT } & Left & 4 & n.s. & $0.05 / .11$ & n.s. & n.s. \\
\hline & Right & 4 & n.s. & n.s. & n.s. & $0.05 / .18$ \\
\hline & Left & 8 & n.s. & $0.05 / .14$ & n.s. & $0.01 / .21$ \\
\hline
\end{tabular}

'Data of January, April and August only / n.s. $=p>0.05$ / SDFT = Superficial digital flexor tendon / DDFT = Deep digital flexor tendon

AL-DDFT $=$ Accessory ligament of DDFT 
The body weight (BW) was obtained by weighing the horses on a transportable commercial scale (Horse weight, Wales, UK). The accuracy of the scale was $\pm 100 \mathrm{~g}$. The weigh scale was not available to weigh the WB in August and December, and neither was it possible to determine their withers height in December.

For the CSA measurements both forelimbs were clipped palmar over the metacarpal area. The skin was thoroughly cleaned, alcohol and ultrasound gel applied (Sonogel® Sonogel Vertriebs $\mathrm{GmbH}$, Bad Camberg, Germany). Structures were measured at four $\mathrm{cm}$ intervals, starting four $\mathrm{cm}$ from the distal border of the accessory carpal bone down to the metacarpophalangeal joint. A tape measure was used to localize the right location for measurements. At each interval the ultrasound picture was frozen and the CSA for each structure measured on the screen. DDFT and AL-DDFT were measured separately as far distal as possible (as far as there was a clear separation line).

A Pie Data Scanner 100 Vet with a $8.0 \mathrm{MHz}$ linear transducer and a commercial off stand was used for all measurements (Pie Data Elektronik GmbH, Dorsten, Germany).

\section{Statistical analyses}

The normal distribution of data was confirmed using the Kolmogorov-Smirnov test. Data are shown as mean \pm standard deviation (STD). Analysis of variance for repeated measures was used to compare among and within breeds, specific distances distal to the accessory carpal bone and forelimbs. Fisher s test was applied as a post-hoc test when significant
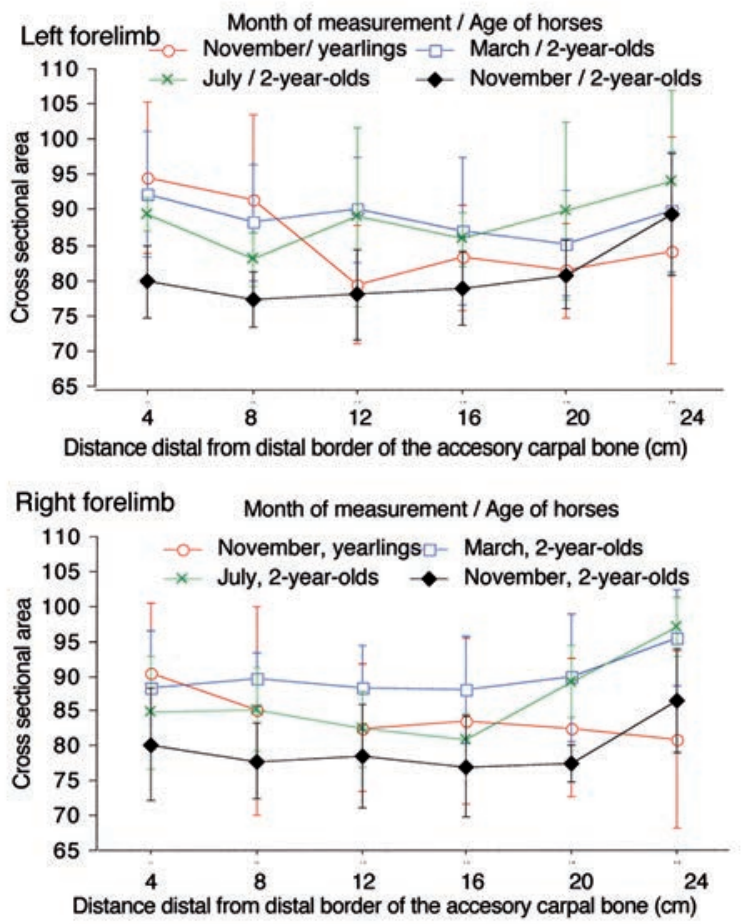

Fig. 1 Development of the cross sectional area $\left(\mathrm{mm}^{2}\right)$ of the superficial digital flexor tendon in the forelimbs of 2-year-old Quarterhorses during one year $(n=5$; Mean \pm STD; Y-Axis starts at $65 \mathrm{~mm}^{2}$ )

Entwicklung der Querschnittsfläche $\left(\mathrm{mm}^{2}\right)$ der oberflächlichen Beugesehne der Vordergliedmaßen von 2jährigen Quarterhorses während eines Jahres ( $n=5$; Mittelwert \pm Standardabweichung; Y-Achse beginnt bei $65 \mathrm{~mm}^{2}$ ) effects were found. The relationship between BW and WH with CSA measurements was investigated with linear regression analysis. $p<0.05$ was defined as the level to denote a significant difference. CSA of AL-DDFT distal to $8 \mathrm{~cm}$ of the distal border of the accessory carpal bone was not analyzed statistically because in many horses it was not separated from DDFT anymore.

\section{Results}

The BW of SB and TB increased continuously while that of $\mathrm{QH}$ had a reduction between the first and second measurement, and then increased continuously only $(p<0.01$ at least for all; Table 1). The BW of WB could not be analyzed because data in August and December were not available. The WH in horses of all breeds increased continuously during the year of observation $(p<0.001$; Table 1).

There were no relationships between BW and CSA of SDFT for either forelimb at the different measuring points distal to the distal border of the accessory carpal bone in QH and TB while in SB there were several, mainly in the right forelimb (Table 2). For DDFT there were no significant relationships with BW in QH and SB and few ones in TB (Table 2). Finally, for AL-DDFT there were no relationships with BW in TB, but some in $\mathrm{QH}$ and SB (Table 2). There were no significant relationships between CSA of SDFT at the different points of measurement and $\mathrm{WH}$ in $\mathrm{QH}, \mathrm{TB}$ and $\mathrm{WB}$ while in SB there were positive relationships at $16 \mathrm{~cm}$ and $20 \mathrm{~cm}$ in both forelimbs (Table 3). For DDFT there were positive relationships with $\mathrm{WH}$ at $12 \mathrm{~cm}$
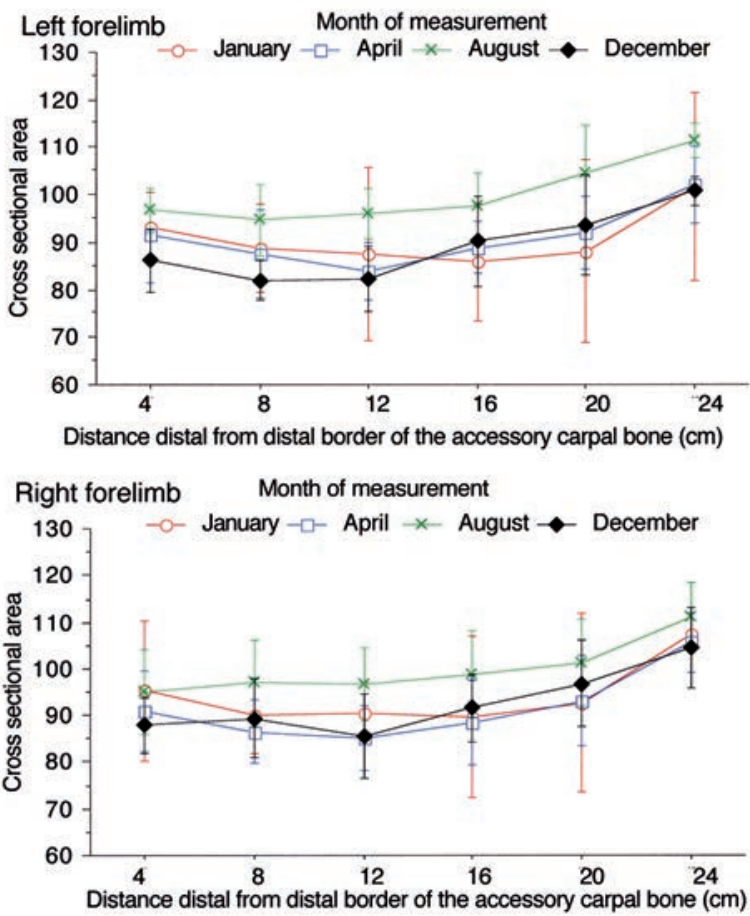

Fig. 2 Development of the cross sectional area $\left(\mathrm{mm}^{2}\right)$ of the superficial digital flexor tendon in the forelimbs of 2-year-old Standardbreds during one year $(n=10$; Mean \pm STD; Y-Axis starts at $60 \mathrm{~mm}^{2}$ )

Entwicklung der Querschnittsfläche $\left(\mathrm{mm}^{2}\right)$ der oberflächlichen Beugesehne der Vordergliedmaßen von 2-jährigen Trabrennpferden während eines Jahres $(n=10$; Mittelwert \pm Standardabweichung; Y-Achse beginnt bei $60 \mathrm{~mm}^{2}$ ) 
distal to the distal border of the accessory carpal bone in both forelimbs of SB and TB only (Table 3). The same holds for the AL-DDFT in $S B$ at $4 \mathrm{~cm}$ and $8 \mathrm{~cm}$ distal to the distal border of the accessory carpal bone of the left forelimb and in WB at $4 \mathrm{~cm}$ in the right forelimb and $8 \mathrm{~cm}$ in the left forelimb.

\section{Superficial digital flexor tendon (SDFT)}

Breed, specific distance distal to the distal border of the accessory carpal bone $(p<0.001$ both) as well as the interaction of breed and specific distance distal to the distal border of the accessory carpal bone had an effect on CSA of SDFT $(p<0.05)$, but there was no effect of forelimb $(p>0.05)$. The CSA of SDFT was smallest in QH, largest in TB and WB while that of SB was in between that of the other breeds. In QH there were few significant changes of SDFT CSA during the year: in the left forelimb CSA decreased $4 \mathrm{~cm}$ distal to the distal border of the accessory carpal bone $(p<0.01)$ and in the right forelimb it decreased at $20 \mathrm{~cm}$, and $24 \mathrm{~cm}(p=0.01$ both). These changes were significant between the second and fourth measurement of the year (Figure 1).

In the right forelimb of SB CSA of SDFT increased $8 \mathrm{~cm}$ and $12 \mathrm{~cm}$ distal to the distal border of the accessory carpal bone only ( $p<0.05$ and $p<0.01$ resp.) while in the left forelimb CSA increased at all specific distances distal to the distal border of the accessory carpal bone but for $24 \mathrm{~cm}(p<0.05$ at least). The increases occurred within the first three measurement dates but became significant at several specific distances distal to the distal border of the accessory carpal bone between the first and third measurement date only $(p<0.05$
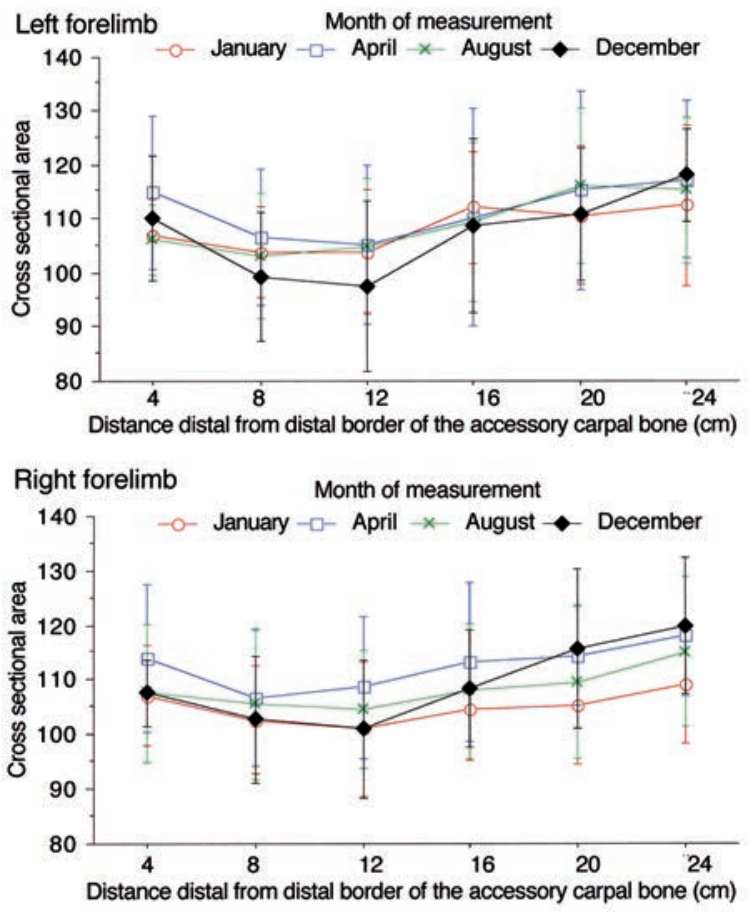

Fig. 3 Development of the cross sectional area $\left(\mathrm{mm}^{2}\right)$ of the superficial digital flexor tendon in the forelimbs of 2-year-old Thoroughbreds during one year $(n=6$; Mean \pm STD; Y-Axis starts at $80 \mathrm{~mm}^{2}$ )

Entwicklung der Querschnittsfläche $\left(\mathrm{mm}^{2}\right)$ der oberflächlichen Beugesehne der Vordergliedmaßen von 2-jährigen Galopprennpferden während eines Jahres $(n=6$; Mittelwert \pm Standardabweichung; Y-Achse beginnt bei $80 \mathrm{~mm}^{2}$ ) at least; Figure 2). There were no changes of CSA of SDFT in any forelimb and specific distances distal to the distal border of the accessory carpal bone in TB during the year of observation ( $p>0.05$ all; Figure 3).

In WB CSA of SDFT decreased during the year at all distances distal to the distal border of the accessory carpal bone (at least $p=0.01$ ) in the right forelimb while this holds for CSA at $4 \mathrm{~cm}, 8 \mathrm{~cm}, 12 \mathrm{~cm} \mathrm{(p<0.001} \mathrm{all)} \mathrm{and} 24 \mathrm{~cm}$ only in the left forelimb $(p<0.05)$. The largest decreases were between the first and second measurement date in both forelimbs (all at least $p<0.05$ ) and values tended to remain stable or decrease less thereafter (Figure 4).

\section{Deep digital flexor tendon (DDFT)}

Breed, distance distal to the distal border of the accessory carpal bone as well as the interaction of breed and distance distal to the distal border of the accessory carpal bone had an effect on CSA of DDFT ( $<<0.001$ all), while forelimb did not $(p>0.05)$. The CSA of DDFT was smaller in QH than in horses of all other breeds $(p<0.01)$ while there were no distinct differences among the others $(p>0.05)$.

Few changes of DDFT CSA occurred during the observation period in $\mathrm{QH}$. It decreased continuously during the observation period at $12 \mathrm{~cm}$ distal of the distal border of the accessory carpal bone ( $p<0.01$; Figure 5).

In SB CSA of DDFT changed during the observation in both forelimbs at all specific distances distal to the distal border of
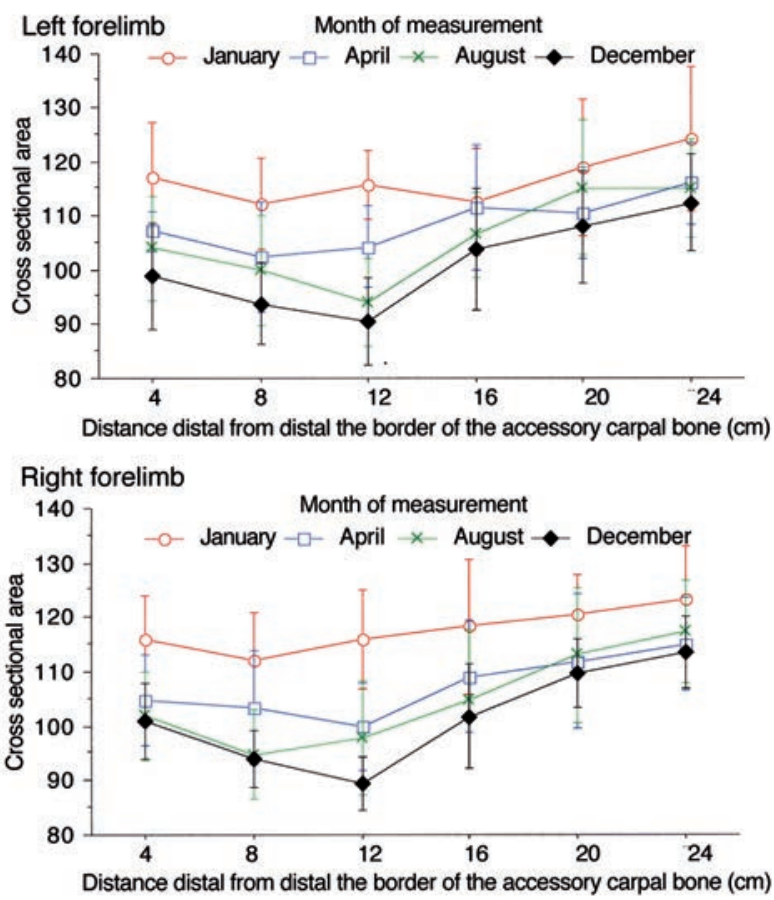

Fig. 4 Development of the cross sectional area $\left(\mathrm{mm}^{2}\right)$ of the superficial digital flexor tendon in the forelimbs of 2-year-old German Warmblood Riding Horses during one year $(n=10$; Mean \pm STD; Y-Axis starts at $80 \mathrm{~mm}^{2}$ )

Entwicklung der Querschnittsfläche $\left(\mathrm{mm}^{2}\right)$ der oberflächlichen Beugesehne der Vordergliedmaßen von 2-jährigen Deutschen Warmblutpferden während eines Jahres $(n=10$; Mittelwert \pm Standardabweichung; Y-Achse beginnt bei $80 \mathrm{~mm}^{2}$ ) 
the accessory carpal bone but for $16 \mathrm{~cm}(\mathrm{p}>0.05)$. In both forelimbs the CSA decreased at $4 \mathrm{~cm}, 8 \mathrm{~cm}$ and $12 \mathrm{~cm}$ during the year of observation while at $20 \mathrm{~cm}$ and $24 \mathrm{~cm}$ it increased between January and August and returned thereafter to the initial levels ( $p<0.05$ at least; Figure 6).

In TB there were no changes of the CSA of DDFT but for an increase $16 \mathrm{~cm}$ distal to the distal border of the accessory carpal bone in the right forelimb from January to April to August $(p<0.01$ both). Values returned to the initial level thereafter $(p<0.05$; Figure 7).

In WB CSA of DDFT decreased continuously during the observation period at the specific distances distal to the distal border of the accessory carpal bone of $8 \mathrm{~cm}, 20 \mathrm{~cm}$ and $24 \mathrm{~cm}$ in the left forelimb $(p<0.01$ at least) and at the same distances distal to the distal border of the accessory carpal bone and at $12 \mathrm{~cm}$ in the right forelimb ( $<0.01$ at least; Figure 8).

Accessory ligament of the deep digital flexor tendon (ALDDFT)

The CSA of the AL-DDFT could not be measured accurately below the level of $8 \mathrm{~cm}$ in most QH and SB, in two of six TB and one of ten WB. Thus, this evaluation was done for $4 \mathrm{~cm}$ and $8 \mathrm{~cm}$ distal of the border of the accessory carpal bone only.

Pooled data of all horses, specific distances distal to the distal border of the accessory carpal bone and dates showed that the development of AL-DDFT CSA differed among breeds and specific distances distal to the distal border of the accessory carpal bone $(p<0.001$ both) and there were no diffe-

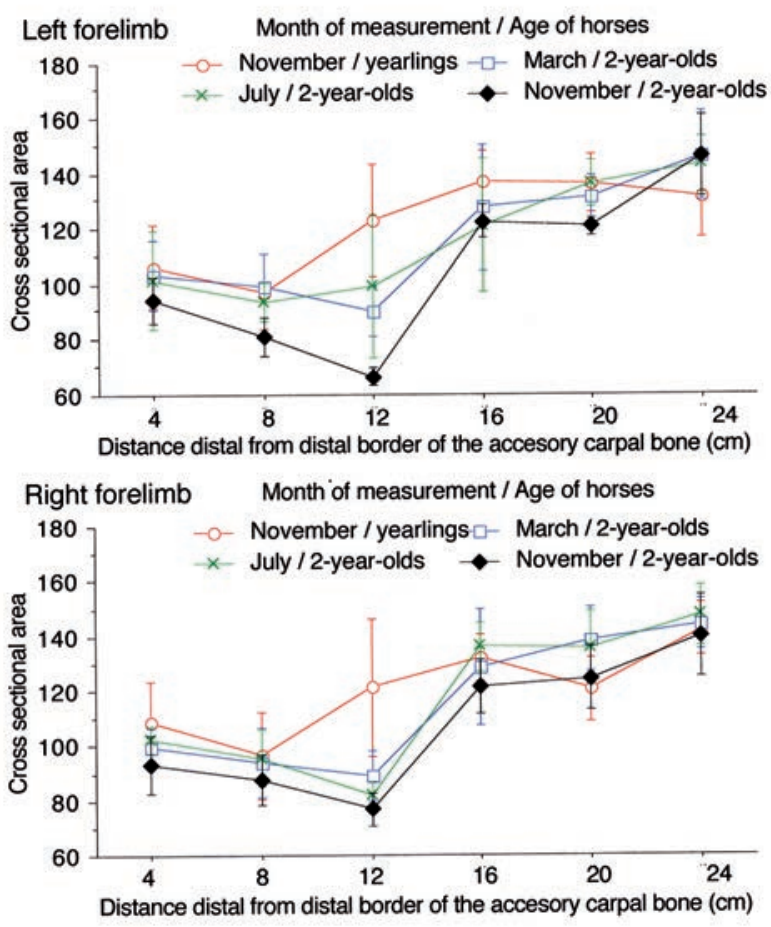

Fig. 5 Development of the cross sectional area $\left(\mathrm{mm}^{2}\right)$ of the deep digital flexor tendon in the forelimbs of 2-year-old Quarterhorses during one year $\left(\mathrm{n}=5\right.$; Mean \pm STD; Y-Axis starts at $\left.60 \mathrm{~mm}^{2}\right)$ Entwicklung der Querschnittsfläche $\left(\mathrm{mm}^{2}\right)$ der tiefen Beugesehne der Vordergliedmaßen von 2-jährigen Quarterhorses während eines Jahres ( $n=5$; Mittelwert \pm Standardabweichung; Y-Achse beginnt bei $60 \mathrm{~mm}^{2}$ ) rences between forelimbs $(p>0.05)$. QH had the smallest CSA of AL-DDFT ( $p<0.01$ at least) while it did not differ significantly among the horses of the other breeds $(p>0.05$ among them).

Separating the data by breed, specific distances distal to the distal border of the accessory carpal bone and date demonstrated no change during the observation year at any specific distance distal to the distal border of the accessory carpal bone and forelimb on the CSA of AL-DDFT in QH ( $p>0.05$ all).

In SB CSA of AL-DDFT increased $8 \mathrm{~cm}$ distal to the distal border of the accessory carpal bone in the left forelimb between January and August and then decreased below the initial value by December. There were no significant changes in the right forelimb $(p>0.05)$.

There were no changes of CSA of AL-DDFT in the left forelimb of TB while in the right forelimb CSA increased continuously $4 \mathrm{~cm}$ and $8 \mathrm{~cm}$ distal to the distal border of the accessory carpal bone between January and August and returned then to the levels measured at the beginning of the observation year $(p<0.05$ at least). In WB CSA of AL-DDFT decreased continuously during the year of observation at all specific distances distal to the distal border of the accessory carpal bone in both forelimbs $(p<0.01$ at least).

\section{Discussion}

This study presents data on the development of the CSA of flexor tendons in the metacarpal region of the forelimbs of horses

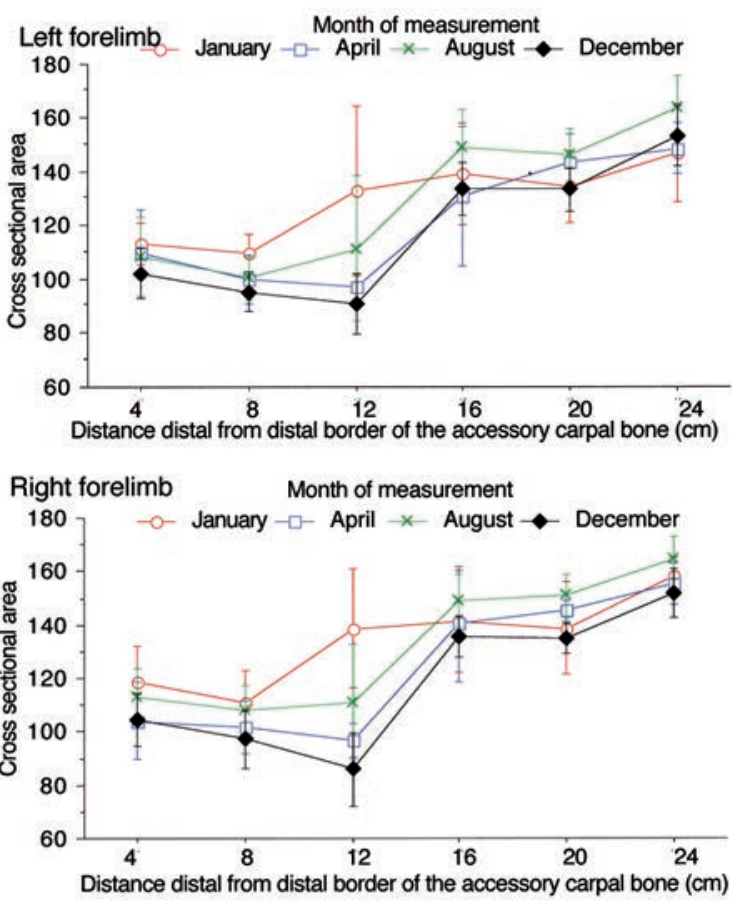

Fig. 6 Development of the cross sectional area $\left(\mathrm{mm}^{2}\right)$ of the deep digital flexor tendon in the forelimbs of 2-year-old Standardbreds during one year $\left(\mathrm{n}=10\right.$; Mean \pm STD; Y-Axis starts at $\left.60 \mathrm{~mm}^{2}\right)$ Entwicklung der Querschnittsfläche $\left(\mathrm{mm}^{2}\right)$ der tiefen Beugesehne der Vordergliedmaßen von 2-jährigen Trabrennpferden während eines Jahres ( $n=10$; Mittelwert \pm Standardabweichung; Y-Achse beginnt bei $\left.60 \mathrm{~mm}^{2}\right)$ 
of four different breeds during their 2-year-old season. Studies describing the CSA of flexor tendons in horses have been published before, but not for QH and WB. In the majority of studies the CSA of SDFT was measured in TB (Gillis et al. 1995a, Celimli et al. 2004, Smith et al. 2004, Reis and Baccarin 2010, Pickersgill et al. 2011). Other breeds for which CSA of SDFT has been described are SB (Herslow et al. 2001, Voswinkel 2009), National Hunt horses (Pickersgill et al. 2011 ), ponies and Irish Draught horses (Smith et al. 1994), Haflinger (Boehart et al. 2010), Purebred Spanish Horses (Agut et al. 2009) and Purebred Arabians (Celimli et al. 2004).

The development of CSA of SDFT varied markedly among horses of the breeds examined in this study. In TB it did not change at all despite being in training for racing (Lindner et al. 1992 a, b), in QH and WB there were significant decreases with varying magnitude among specific distances distal to the distal border of the accessory carpal bone, and in SB there were significant increases between January and August, when the volume or the intensity of racing training increased continuously (Wegener et al. 2012) and a decrease thereafter when the training volume was reduced. Few other groups have investigated the development of CSA of SDFT in horses under practice conditions. Again the majority of these studies are in TB (Gillis et al. 1993, Perkins et al. 2004) but for one in SB (Voswinkel 2009). The study of Cherdutham et al. (2001 a) was on Dutch Warmblood foals not comparable to the age group examined in this study, but they found that the SDFT of foals with free pasture exercise had larger CSA than in those kept in box or given additional exercise. Also Voswinkel (2009) observed a larger increase of the CSA of SDFT in SB between 50 and 500 days old that moved more than others.
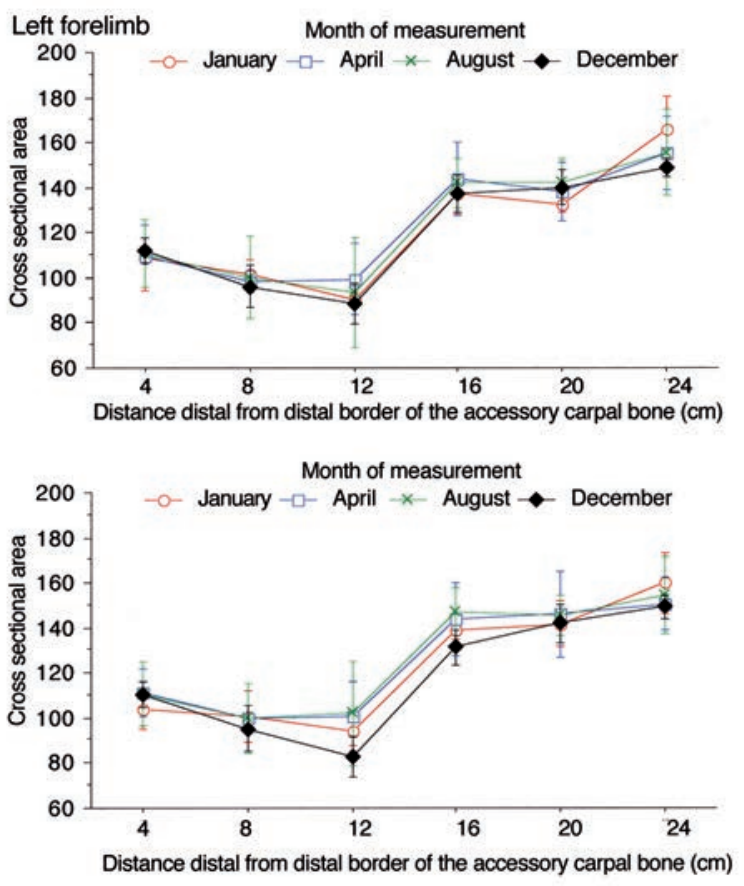

Fig. 7 Development of the cross sectional area $\left(\mathrm{mm}^{2}\right)$ of the deep digital flexor tendon in the forelimbs of 2-year-old Thoroughbreds during one year $\left(\mathrm{n}=6\right.$; Mean \pm STD; Y-Axis starts at $\left.60 \mathrm{~mm}^{2}\right)$ Entwicklung der Querschnittsfläche $\left(\mathrm{mm}^{2}\right)$ der tiefen Beugesehne der Vordergliedmaßen von 2jährigen Galopprennpferden während eines Jahres ( $n=6$; Mittelwert \pm Standardabweichung; Y-Achse beginnt bei $\left.60 \mathrm{~mm}^{2}\right)$
Moffat et al. (2008) followed TB kept from 5 to 18 months of age either on pasture with free exercise only or with additional conditioning exercise 5 days per week and observed in both groups the greatest increase of SDFT CSA between 5 and 8 months of age and that this increase tended to be larger in the horses with the additional conditioning exercise. Finally, Perkins et al. (2004) describe an increase of CSA of SDFT, pooled over five measurement levels, in 2 -year-old TB trained during 13 weeks in comparison to an untrained group. However, the mean SDFT CSA in the trained group was not significantly different from the pre-training level.

The findings in the cited studies and in the present one allow for the assumption that physical training increases CSA of SDFT in horses. This has been shown to some extent in experimental studies in TB of different age too (Birch et al. 1999a, Kasashima et al. 2002). The same holds for studies done in other mammals (Elliott 1965) and in man where strength training, repetitive and intermittent loading type of training increase CSA of patellar and Achilles tendon (Rosager et al. 2002, Kongsgaard et al. 2005, Kongsgaard et al. 2007, Arampatzis et al. 2007, Seynnes et al. 2009) possibly making it more resistant to injuries. It remains to be better examined whether this is the case in horses too (Firth 2006), but Cherdchutham et al. (2001 a) describe higher loads to rupture in Dutch WB foals with larger CSA of SDFT than in those with smaller CSA. This finding is supported by the clinical observation of Smith et al. (1994) in a study on healthy tendons that TB with SDFT lesions had smaller CSA. Thus, increasing CSA of SDFT could reduce injury rate although this may not be attributable only to the larger CSA but also to adaptations in collagen fibril diameter distribution (Cherd-
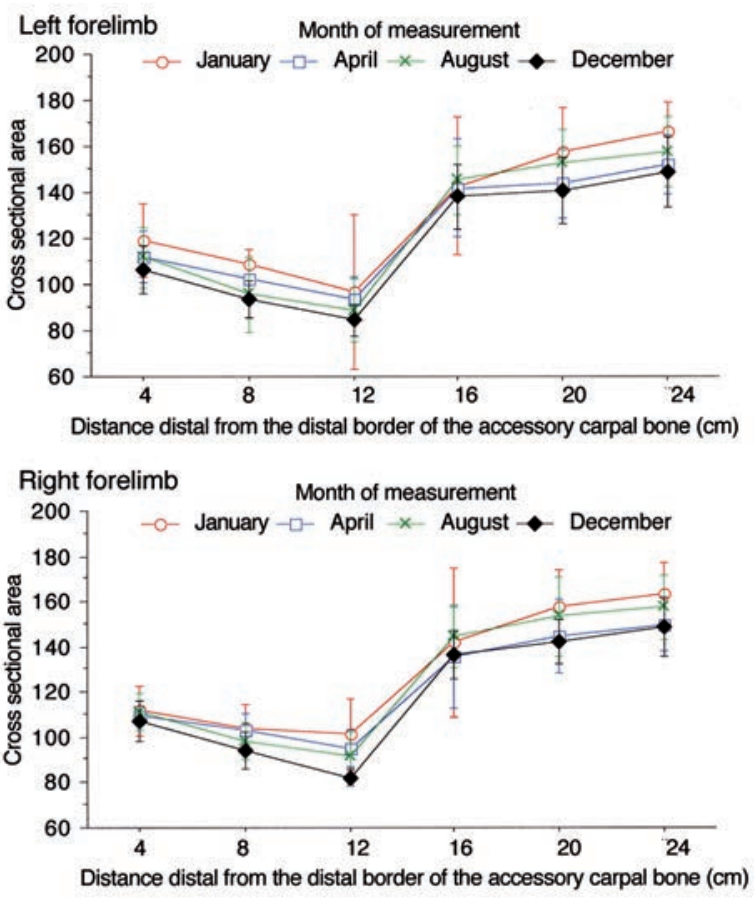

Fig. 8 Development of the cross sectional area $\left(\mathrm{mm}^{2}\right)$ of the deep digital flexor tendon in the forelimbs of 2-year-old German Warmblood Riding Horses during one year $(n=10$; Mean \pm STD; Y-Axis starts at $60 \mathrm{~mm}^{2}$ ) / Entwicklung der Querschnittsfläche $\left(\mathrm{mm}^{2}\right)$ der tiefen Beugesehne der Vordergliedmaßen von 2-jährigen Deutschen Warmblutpferden während eines Jahres $(n=10$; Mittelwert \pm Standardabweichung; Y-Achse beginnt bei $60 \mathrm{~mm}^{2}$ ) 
chutham et al. 2001 b) and biochemical composition of the tendon (Cherdchutham et al. 1999).

In this study, the only horses with an increase of CSA of SDFT were the SB, albeit it decreased again towards the end of the observation period. In TB there was no change at all and in QH and WB decreases only. Genetics are likely to play a role, but training could be of importance too in the development of flexor tendons. The obvious difference between the training of SB and TB is that SB pull a sulky at trot speeds of up to 14 $\mathrm{m} / \mathrm{s}$ while TB gallop under a rider for speeds of up to $20 \mathrm{~m} / \mathrm{s}$. In addition, SB are exercised for longer duration at moderate speeds than TB (Lindner et al. 1992 a and b, Voswinkel 2009, Wegener et al. 2012) while intensity and duration of the training of the $\mathrm{QH}$ and WB involved was much lower and shorter than in SB and TB. Elliott (1965) conclude already that the CSA of a tendon might be related to the average tension transmitted and possibly to the duration of the effort. Another indication of a physical training effect is the decrease of CSA of SDFT in SB to the levels before August between August and December, a period when training workload is reduced towards the end of the year.

The CSA of DDFT in 2-year-old horses of all breeds studied had fewer changes during the year of observation than the SDFT, but changes differed among breeds too. In TB again there were almost no changes during the year, and the same holds in QH. In SB development depended on the distance distal to the distal border of the accessory carpal bone: CSA values reduced between January and August at the more proximal levels while at the distal levels they augmented. Thereafter, between August and December values at all levels returned to levels before August. Diverse effects of loading at different levels of tendons have been described before in man too (Rosager et al. 2002, Kongsgaard et al. 2005, Kongsgaard et al. 2007).

In WB CSA of DDFT decreased continuously during the observation period at several specific distances distal to the distal border of the accessory carpal bone in both forelimbs. The only other published study that looked into the changes of DDFT CSA with time is the one of Voswinkel in SB (2009). Voswinkel (2009) measured larger CSA of DDFT in SB that moved more. All other studies provide reference data on CSA of DDFT only: for TB Smith et al. (1994) and Gillis et al. (1995 a), for Haflinger Boehart et al. (2010), for SB Herslow et al. (2001) and for Purebred Spanish Horses Agut et al. (2009). Overall, the data basis for assuming that physical training had an effect on CSA of DDFT is much smaller than for CSA of SDFT, but the same arguments presented earlier in this article for SDFT may provide for such a hypothesis too. The differential behaviour of the more proximal and more distal distances to the distal border of the accessory carpal bone might be due to contrasting biomechanical effects of gait and loading in horses.

The CSA of AL-DDFT could not be measured distal of $8 \mathrm{~cm}$ from the border of the accessory carpal bone in most 2-yearold QH and SB, in two of six TB and one of ten WB because it became one with the DDFT. Therefore, for comparison purposes the measurements $4 \mathrm{~cm}$ and $8 \mathrm{~cm}$ distal to the distal border of the accessory carpal bone only were analyzed further. Here too, the development of AL-DDFT CSA differed among breeds and specific distances distal to the distal border of the accessory carpal bone. The CSA of AL-DDFT in QH did not change during the observation year, in WB it decreased continuously at all specific distances distal to the distal border of the accessory carpal bone and in both forelimbs, in SB it increased $8 \mathrm{~cm}$ distal to the distal border of the accessory carpal bone in the left forelimb between January and August and then decreased below the initial value by December. In the TB it increased continuously at $4 \mathrm{~cm}$ and $8 \mathrm{~cm}$ distal to the distal border of the accessory carpal bone between January and August and returned then to the levels measured at the beginning of the observation period, but in the right forelimb only. In general terms the developmental trends of AL-DDFT are similar to those of SDFT and DDFT in horses of the different breeds, but for in TB. A satisfactory explanation for this contrasting behaviour of the right forelimb in TB is not available at present. In literature no description of the development of ALDDFT over time was found being the least investigated of the tendons measured in this study. Reference data is provided for TB by Smith et al. (1994), for Purebred Spanish Horses by Agut et al. (2009) and for Haflinger by Boehart et al (2010).

BW and $\mathrm{WH}$ were related positively with CSA of SDFT, DDFT and AL-DDFT when data of all horses, measurement levels and dates were pooled for analysis. These relationships imply that the comparison of the CSA of flexor tendons among breeds does not make much sense. The relationships became less frequent and evident after differencing for breed and the specific distances distal to the distal border of the accessory carpal bone. This is logical due to the much lower number of values and eventually smaller spread of them in each comparison category. However, it shows also that other factors besides BW and WH play roles in determining CSA of flexor tendons in horses. Several other authors have found positive relationships between BW and CSA of SDFT, DDFT (in ponies Smith et al. 1994, in SB Voswinkel 2009) and even AL-DDFT (in ponies Smith et al. 1994). Purebred Spanish Horses with higher body mass index (BMI) had higher CSA of SDFT, DDFT and AL-DDFT too (Agut et al. 2009). In contrast, Boehart et al. (2010) did not find a relationship between BMI and CSA of SDFT and DDFT in Haflinger and neither did Smith et al. (1994) in Irish Draught Horses and TB between BW and CSA of SDFT, DDFT and AL-DDFT and Gillis et al. (1995 a, b) for SDFT in 2-year-old TB. The WH and CSA of SDFT and DDFT were related in SB according to Voswinkel (2009) and in ponies - including AL-DDFT - according to Smith et al. (1994), whilst Boehart et al. (2010) did not find a relationship between WH and CSA of SDFT and DDFT in Haflinger, but for a higher CSA of DDFT $16 \mathrm{~cm}$ distal to the distal border of the accessory carpal bone, and Smith et al. (1994) none in Irish Draught horses and TB. Thus, BW and WH are factors related to some extent positively with the CSA of the flexor tendons in horse, but other factors like the level of activity at the date of measurement and during life might have a larger influence.

\section{Conclusions}

The most important finding in this study is the differential change of CSA of SDFT in horses of different breeds during the observation period. As the different breeds underwent substantially different training programmes, this can indicate that training may affect CSA of the SDFT which in turn may 
have an influence on injury resistance. This is vital for raceand sporthorses because SDF tendonitis is among the most common of their musculoskeletal injuries (Gibson et al. 2002, Murray et al., 2006, Singer et al. 2008, PattersonKane and Firth 2009, O'Meara et al 2010, Clegg 2012). Prove of this could be provided by examining the effect of the physical training of SB in horses of other breeds and through long-term sonographic follow up of the CSA of flexor tendons in horses during their sports career.

\section{Acknowledgements}

The authors are very grateful to all owners and trainers that provided horses for this study and Sheila Schils for revising the manuscript.

\section{References}

Agut A., Llanos Martinez M., Sanchez-Valverde M. A., Soler M., Rodriguez M. J. (2009) Ultrasonographic characteristics (crosssectional area and relative echogenicity) of the digital flexor tendons and ligaments of the metacarpal region in Purebred Spanish horses. Vet. J. 180, 377-383

Arampatzis A., Karamanidis K., Albracht K. (2007) Adaptational responses of the human Achilles tendon by modulation of the applied cyclic strain magnitude. J. Experimen. Biol. 210, 2743-2753

Birch H. L., Bailey J. V. B., Bailey A. J., Goodship A. E. (1999a) Agerelated changes in the molecular and cellular components of equine flexor tendons. Eq. Vet. J. 31, 391-396

Birch H. L., McLaughlin L., Smith R. K., Goodship A. E. (1999 b) Treadmill exercise-induced tendon hypertrophy: assessment of tendons with different mechanical functions. Eq. Vet. J. Suppl. 30, 222-226

Boehart S., Arndt G., Carstanjen B. (2010) Ultrasonographic Morphometric Measurements of Digital Flexor Tendons and Ligaments of the Palmar Metacarpal Region in Haflinger Horses. Anatom. Histol. Embryolog. 39, 366-375

Cherdchutham W., Becker C., Smith R. K. W., Barneveld A., van Weeren P. R. (1999) Age-related changes and effect of exercise on the molecular composition of immature equine superficial digital flexor tendon in foals. Eq. Vet. J. Suppl. 31, 86-94

Cherdchutham W., Meershoek L. S., van Weeren P. R., Barneveld A. (2001 a) Effects of exercise on biomechanical properties of the superficial digital flexor tendon in foals. Am. J. Vet. Res. 62, 1859-1864

Cherdchutham W., Becker C. K., Spek E. R., Voorhout W. F., van Weeren P. R. (2001 b) Effects of exercise on the diameter of collagen fibrils in the central core and periphery of the superficial digital flexor tendon in foals. Am. J. Vet. Res. 62, 1563-1570

Celimli N., Seyrek-Intas D., Kaya M. (2004) Morphometric measurements of flexor tendons and ligaments in Arabia Horses by ultrasonographic examinations and comparison with other breeds. Eq. Vet. Edu. 16, 81-85

Clegg P. D. (2012) Musculoskeletal disease and injury, now and in the future. Part 2: Tendon and ligament injuries Eq. Vet. J. 44 371-375

Elliott D. H. (1965) Structure and function of mammalian tendon. Biological Review 40, 392-421

Firth E. C. (2006) The response of bone, articular cartilage and tendon to exercise in the horse. Review. J Anat. 208, 513-526

Gibson K. T., Snyder J. R., Spier S. J. (2002) Ultrasonographic diagnosis of soft tissue injuries in horses competing at the Sydney 2000 Olympic Games. Eq. Vet. Edu. 14, 149-156

Gillis C. L., Meagher D., Pool R., Stover S. M., Craychee T.J., Willits N. (1993) Ultrasonographically detected changes in equine superficial digital flexor tendons during the first months of race training. Am. J. Vet. Res. 54, 1797-1802

Gillis C., Meagher D. M., Cloninger A., Locatelly L., Willits N. (1995a) Ultrasonographic cross-sectional area and mean echogenicity of the superficial and deep digital flexor tendons in 50 trained Thoroughbred racehorses. Am. J. Vet. Res. 56 1265-1269
Gillis C., Sharkey N.. Stover S. (1995b) Effect of maturation and ageing on material and ultrasonographic properties of equine superficial digital flexor tendon. Am. J. Vet. Res. 56, 1345-1350

Herslow J., Uhlhorn M., Uhlhorn H. H. (2001) Cross-sectional area of the superficial and deep digital flexor tendon in Standardbred Trotters: an ultrasonographic field study. In: Proc. 8th Annual Congress of the Europ. Assoc. Vet. Diagnos. Imag., Paris, France, pp 92

Kasashima Y., Smith R. K., Birch H. L., Takahashi T., Kusano K. Goodship A. E. (2002) Exercise-induced tendon hypertrophy: cross-sectional area changes during growth are influenced by exercise. Eq. Vet. J. Suppl. 34, 264-268

Kongsgaard M., Aagaard P., Kiaer M. Magnusson S. P. (2005) Structural Achilles tendon properties in athletes subjected to different exercise modes and in Achilles tendon rupture patients. J. Appl. Physiol. 99, 1965-1971

Kongsgaard M., Reitelseder S., Pedersen T. G., Holm L., Aagaard P., Kjaer M. Magnusson S. P. (2007) Region specific patellar tendon hypertrophy in humans following resistance training. Acta Physiol. (Oxford) 191, 111-121

Lindner A., von Wittke P., Baver S. (1992 a) Training and contents of training for Thoroughbred racehorses. Part I: Extent and intensity of training at the beginning of the racing season among two year old and older Thoroughbred racehorses. Pferdeheilkde. 8, 175-180

Lamas L. P., Giovagnoli G., Heath M. F., Jeffcott L. B. (2007)Some factors affecting the accuracy and variability of measurements of the height of ponies. Veterinary Record 160, 691-694

Lindner A., von Wittke P., Esser L. (1992 b) Training and contents of training in thoroughbred race horses. Part 2: Extent and intensity of training and terms used in practice to specify contents of training. Pferdeheilkunde 8, 311-320

Moffat P. A., Firth E. C., Rogers C. W., Smith R. K. W., Barneveld A., Goodship A. E., Kawcak C. E., Mcllwraith C. W., van Weeren P. R. (2008) The influence of exercise during growth on ultrasonographic parameters of the superficial digital flexor tendon of young Thoroughbred horses. Eq. Vet. J. 40, 136-140

Murray R. C., Dyson S. J., Tranquille C., Adams V. (2006) Association of type of sport and performance level with anatomical site of orthopaedic injury diagnosis. Eq. Vet. J. Suppl. 36, 411-416

O'Meara B., Bladon B., Parkin T. D. H., Fraser B.. Lischer C. J. (2010) An investigation of the relationship between race performance and superficial digital flexor tendonitis in the Thoroughbred racehorse. Eq. Vet. J. 42, 322-326

Patterson-Kane J. C.. Firth E. C. (2009) The pathobiology of exercise-induced superficial digital flexor tendon injury in Thoroughbred racehorses. Review. Vet. J. 181, 79-89

Perkins N. R., Rogers C. W., Firth E. C.. Anderson B. H. (2004) Musculoskeletal responses of 2-year-old Thoroughbred horses to early training. 3. In vivo ultrasonographic assessment of the crosssectional area and echogenicity of the superficial digital flexor tendon. New Zealand Vet. J. 52, 280-284

Pickersgill C. H., Marr C. M.. Reid S. W. (2001) Repeatability of diagnostic ultrasonography in the assessment of the equine superficial digital flexor tendon. Eq. Vet. J. 33, 33-37

Reis A. G. M. S. Baccarini R. Y. A. (2010) The cross-sectional area of the superficial digital flexor tendon of trained and untrained Thoroughbred racehorses. Ciência Rural, Santa Maria, Brazil 40, 1786-1790

Rosager S., Aagaard P., Dyhre-Poulsen P., Neergaard K., Kiaer M., Magnusson S. P. (2002)Load-displacement properties of the human triceps surae aponeurosis and tendon in runners and nonrunners. Scand. J. Med. Sci. Sports 12, 90-98

Seynnes O. R., Erskine R. M., Maganaris C. N., Longo S., Simoneau E. M., Grosset J. F., Narici M. V. (2009) Training induced changes in structural and mechanical properties of the patellar tendon are related to muscle hypertrophy but not to strength gains. J. Appl. Physiol. 107, 523-530

Singer E. R., Barnes J., Saxby F., Murray J. K. (2008) Injuries in the event horse: training versus competition. Vet. J. 175, 76-81

Smith R. K. W., Jones R., Webbon P. M. (1994) The cross-sectional areas of normal equine digital flexor tendons determined ultrasonographically. Eq. Vet. J. 26, 460-465

Voswinkel L. (2009) Einfluss der Bewegungsaktivität auf Wachstumsund Ausdaverparameter beim Pferd. Doctoral Thesis Agronomy Kiel, Germany

Wegener J., Lindner A., Hartmann U. (2012) Survey on the training of Standardbred racehorses by a successful trainer. Pferdeheilkunde. $28,268-280$ 